\title{
The Decision Commentary of the European Court of Human Rights, Case O'Kefle Vs. Irland
}

\author{
Desart Avdulaj \\ PhD Candidate, "University of Tirana" \\ Email, desartavdulaj@yahoo.com \\ Indrit Shtupi, PhD \\ Lecturer of "Windom University" \\ Email, indritshtupi@yahoo.com
}

Doi:10.5901/mjss.2016.v7n2s1p560

\begin{abstract}
In August 1949, in the framework of the prerogatives and its role, just three months after the establishment of the Council of Europe, its Assembly consultative session her first took on the task of drafting a document which would be guaranteed rights and fundamental freedoms of the individual. After depositing and ratification by ten states, the Convention entered into force on 3 September 1953. Now it has become almost a condition "sine qua non" for membership in the Council of Europe. European countries, members of the Council of Europe and signatory to the European Convention for the protection of Human Rights and Fundamental Freedoms and 11th protocols to the Convention are obliged to undertake all individuals under their jurisdiction to enable the effective enjoyment of their human rights and fundamental freedoms, at least to the minimum provided for in the Convention. They are also obliged to its citizens, non-governmental organizations, other groups and individuals as well as foreigners who stay in their territory to enable the application to the European Court of Human Rights in Strasbourg. In this perspective the purpose of this article is to comment the recent decision of the ECHR, taken on 28.01.2014, a decision in which the Court expressly recognized that we are dealing with a series of violations of the Convention and some of its articles specifically. The case dealt with the issue of State responsibility for sexual abuse of a 9-year-old schoolgirl, a teacher in a National School Ireland in 1973. The issue seemed very interesting, as cases of maltreatment and sexual violence against minors in Albania They were present. The case of Robin Arnold sentenced in 2010 by the Tirana Court and then the Court of Appeal to 15 years and 6 months mother on charges of sex with minors. Carl Stephan Kaminski, 70-year-old living in Durres, charged and later convicted. Fatbardh Çekrezi, Iris Misku are just some of the names of convicted by Albanian justice on charges of sexual relations or homosexual relations with minors.
\end{abstract}

Keyword: Convention, Council of Europe, minors, relations, sexual abuse, European Court of Human Rights.

\section{O'Keefe Case vs. Ireland, Key Facts}

The applicant, Louise O'Keeffe, is an Irish citizen who was born in 1964 and lives in Cork (Ireland). Since 1968 the then Ms. O'Keeffe went to a National School, like most Irish children. Then national schools were primary schools financed by the state which were privately managed under the patronage Religious (mainly Catholic). Ms. O'Keefe School, the National School Dunderrow, was owned by the Catholic Diocese of Cork and Ross, the owner of which was Bishop of Cork and Ross and is managed by a priest (Ó). ${ }^{1}$

In 1971, a parent of a child complained to the owner "O", that the principal Dunderrow (L.H), a secular teacher, had sexually abused her daughter. After the complaint was followed by further complaints in 1973, L.H left school and went for medical treatment where and then left the teaching profession temporarily in September of that year. In January 1974, "Ó" informed the then Department of Education and Science L.H's resignation.

L.H then went in another national school, in which he gave lectures to 1995, the year of his pension retirement. The Police Department was not informed around L.H since no complaints were registered with the police for Mr. L.H around his sexual abuse presumptions. ${ }^{2}$

From January to mid-1973 Ms. O'Keeffe underwent a considerable number of sexual assaults by LH. After this period Ms. O'Keeffe showed psychological problems, which it failed to connect those concerns with sexual abuse to

1 Fenwick, H. \& Phillipson, G. (2003). "Text, Cases and Materials on Public Law and Human Rights", pg. 968.

2 O'keefe case vs. Ireland, Key Facts. (2004). Irish Law Times Including Irish Law Log, Volume 22, Round Hall Press. 
which he had been a victim.

In the course of a criminal investigation complaint against LH from a former pupil of the school Dunderrow in the mid-1990s, police contacted Ms. O'Keeffe where he made a statement in January 1997 statement in which she showed around sexual abuse that had suffered. During the investigation the number of students as victims of these abuses came and dissension. Finally, L.H was charged with 386 criminal acts of sexual abuse of minors involving some 21 former students of Dunderrow. In 1998, he pleaded guilty to 21 counts and sentenced to imprisonment. ${ }^{3}$

After hearing the testimony of other victims during criminal proceedings and after L.H's medical treatment, Ms. O'Keeffe managed to create its connection between psychological problems and sexual violence suffered by L.H.

In September 1998 she deposited a civil lawsuit against L.H, against the Ministry of Education and Science, and deposited a lawsuit against Ireland and the Attorney General, seeking damages for personal injuries suffered as a result of sexual abuse.

In October 1998 she deposited a lawsuit to Damages Criminal Court which awarded her 53,962.24 euros (EUR).

She said: That the state had failed to put in place measures and procedures appropriate to prevent and stop the systematic abuse $\mathrm{LH}$, that the state was indirectly responsible as the employer of $\mathrm{LH}$, and that the state was responsible as Educational Provider under Article 42 of the Constitution.

L.H lost the civil lawsuit in October 2006 that the Supreme Court ordered him to pay Ms O'Keeffe EUR 305104 compensation. Following enforcement proceedings, in which L.H, claimed that it did not have Sufficient Funds, was ordered to pay Ms. O'Keeffe Euro 400 per month. ${ }^{4}$

In March 2004, the High Court dismissed the claims of Ms. O'Keeffer regarding with the negligence of the state. In January 2006, the Supreme Court declared that the state was not vicariously responsible for sexual assaults of L.H rejecting her constitutional claim.

In December 2008, the Supreme Court rejected the appeal of Ms. O'Keeffe regarding responsibility came from the State. The Supreme Court noted that the system of Irish primary school should be understood in the specific context of history at the beginning of the XIX century, while the state was simply funding system, the role of management of the church was such that the state cannot be held responsible for actions of the teacher in question.

\section{The appeals, procedure and composition of the Court}

Ms. O'Keeffe appealed that the Irish state had failed twice to structured primary education system in order to protect her from sexual abuse and to investigate or to give an appropriate response of the court to her harassment. It also claimed that he had not been able to be recognized and to claim compensation because of the failure of the state to guarantee its protection. She supported her claim on Article 3 of the ECHR (prohibition of inhuman and degrading treatment) and Article 13 (Right to effective use of funds).

She supported her claim on Article 3 of the $\mathrm{ECHR}^{6}$ (prohibition of inhuman and degrading treatment) and Article 13 (Right to use effective funds). She further complained of a violation of Article 8 (right to respect the private life) and Article 2 of Protocol 1 (right to education), as well as violation of Article 14 (prohibition of discrimination), arguing that sexual abuse had caused disturbances in its important relations, sexual and marriage problems and that she was the victim of discrimination after he was refused the right to be compensated as other abused victims in National schools or Industrial schools. ${ }^{7}$ She also complained based on Article 6 (Fair Trial) and in relation with Article 13, that procedural actions were too long and she has not primarily financial family remedies regarding this.

The application was submitted at the European Court of Human Rights on 16/06/2009. On 26 June 2012the Chamber unanimously struck her complaint concerning the length of civil judicial process and the lack of an effective domestic remedy regarding this, because a settlement was reached between the parties on these issues. The Chamber declared admissible the remaining complaints. ${ }^{8}$

On September 20, 2012 the Chamber relinquished jurisdiction in favor of the Grand Chamber of the remaining

\footnotetext{
${ }^{3}$ http://www.justice.ie/en/JELR/OKeeffe\%20v\%20Ireland.pdf/Files/OKeeffe\%20v\%20Ireland.pdf.

${ }^{4}$ O'keefe case vs. Ireland. (2012). "European Center for Law and Justice", ApplicationNo. 35810/09.

${ }^{5}$ European Convention of Human Rights.

${ }^{6}$ Puto, A. (2002). "European Convention on Human Rights toward the Albanian Constitution", pg. 145.

${ }^{7}$ Rehabilitation and professional schools were established in Ireland around the years 1850-60. These schools were closed around 1970. In the years 1980-1990 were published by the Inquiry Commission "Ryan". With many accusations about clerical abuse made against children in Ireland. In May 2009, was reported many Chronic Abuses, Severe Physical Abuses (including sexual) of children by Clergy mainly in Industrial and Rehabilitation Schools.

${ }^{8}$ Mowbray, A. (2012). "Cases, Materials, and Commentary on the European Convention on Human Rights", pg. 37.
} 
related complaints. A public hearing was held in front of the Grand Chamber in the building of Human Rights, Strasbourg, on 6 March $2013 .{ }^{9}$

The Irish Commission on Human Rights and the European Center for Law and Justice was authorized to intervene as third parties (according to Article $36 \S 2$ of the Convention) in the written procedure.

The decision was given by the Grand Chamber of 17 judges, composed as follows:

Dean Spielmann (Luxembourg), President, Josep Casadevall (Andorra), Guido Raimondi (Italy), Ineta Ziemele (Latvia), Mark Villiger (Liechtenstein), Isabelle Berro-Lefèvre (Monaco), Boštjan M. Zupančič (Slovenia), Alvina Gyulumyan (Armenia), Nona Tsotsoria (Georgia), Zdravko Kalaydjieva (Bulgaria), Nebojša Vučinić (Montenegro), Vincent A. de Gaetano (Malta), Angelika Nußberger (Germany), André Potocki (France), Krzysztof Wojtyczek (Poland), Valeriu Griţco (the Republic of Moldova) and Peter Charleton (Ireland), ad hoc Judge, also Michael O'Boyle, of Civil Status Service.

\section{The decision of the Jury}

\subsection{Article 3: The Abuse}

The Court accepted that, during the hearing of this case, it had to evaluate even the slightest State responsibility regarding the facts and standards of 1973 and especially, regardless awareness today's society around "sexual abuse of minors in a contemporary context of education". 10

The Court also admitted that the model of primary education in Ireland, as a product of the experience of its history, was unique in Europe where the state guarantee for education (through the establishment of curriculum, selection of teachers, licensing and financing of schools) and management of the primary education that was provided by the National School.

The court continued the argument stating that young children are "Vulnerable", and that was an inherent obligation of the government to protect them from abuse, especially in primary education when they are under the exclusive control of the school authorities, by adopting Special measures and Protective measures. A state cannot be justified by the obligation to delegate the current to private bodies. Neither could be released from this obligation, as suggested by the Government, Ms. O'Keeffe could have chosen alternative school options such as home schooling or to pay quota for private school. Education is mandatory according national law and Ms. O'Keeffe had no realistic and acceptable alternative except to attend her local National school, along with the vast majority of children of her age.

The most important question in this case was not the responsibility of $\mathrm{LH}$, a clerical manager, for sexual abuses, which Ms. O'Keeffe was subdued in 1973. Rather, the case in question should determine the responsibility of the State and if this recently should have been aware of the risk of sexual abuse of minors in national schools at the relevant time and if the State had properly protect children, through its legal system, from such ill-treatment?

First, the Court found that the state had to have been aware of the extent of sexual crimes against minors, through the prosecution of such crimes at a significantly before year 1970. A series of reports from the 1930s to the 1970s bore witness detailed statistics on investigations of sexual crimes of the Irish prosecution against the children. The "Ryan" report of May 2009 highlighted the many complaints made to the authorities front and during the 1970s in connection with the sexual abuse of children by adults. ${ }^{11}$ Although the report was focused on Industrial and Reformations schools, numerous complaints of sexual abuse have also been registered in other national schools.

Despite this knowledge, the state continues to entrust the Irish primary education management and the vast majority of young children in Irish National Schools, to the private authorities, without using any effective control mechanism thereof.

Although the government continued to claim that certain mechanisms of detection and reporting of sexual abuse existed, the Court did not consider these measures Sufficiently Effective, as if they were such, then these abuses would not exist.

The government noted in 1965 and the Rules for National Schools and Guidelines of 1970 defining the practice to be followed regarding complaints against teachers. However, not referring to any obligation of national authorities to monitor the treatment of any teacher of children and do not receive any procedure to allow a child or parent who complained of direct mistreatment to a state authority. Guidelines specifically channeling complaints directly to private managers, in general, the local priest as in the case of Ms O'Keeffe. The appeals were made in 1971 and 1973 against

\footnotetext{
$9 \mathrm{http} / / /$ hudoc.echr.coe.int/app/conversion/pdf/?library=ECHR\&id=001-146540\&filename=001-146540.pdf.

10 http://humanrights.ie/announcements/okeeffe-ireland-violated-article-3-echr/.

11 http://www.dcya.gov.ie/documents/publications/implementation_plan_from_ryan_commission_report.pdf.
} 
school manager L.H to Ms O'Keeffe, but the manager did not convey the complaints to any state authority.

Secondly, the school inspection system, through inspectors, supported by the Government, did not refer to any obligation to inquire or obligation to monitor the treatment of any teacher to children. Their task was primarily to oversee and report on the quality of teaching and academic performance. The inspector assigned to the school of Ms. O'Keeffe in Dunderrow made 6 visits during 1969 to 1973, and had not received any complaints regarding L.H and its abuses against young children.

Indeed, any complaints regarding L.H's activities was not made at any state authority until 1995, after his retirement pension. The Court considered that the system of Intelligence and Reporting that allowed over 400 incidents of violence by L.H considered being absolutely ineffective. If you would take, the necessary action to a complaint made in 1971 would have avoided Ms. O'Keeffe mistreatment and sexual abuse that occurred 2 years later by the same teacher.

So, in the case of Ms O'Keeffe, Sexual Abuse (1973) it was due to State Failure to respond to the previous complaints of sexual abuse against LH made in 1971, misconduct and repeated sexual violence by LH on many other students in the same National School.

Therefore, in violation of Article 3, the Irish State has failed to fulfill its obligation for Protection of Ms. O'Keeffe from sexual abuse to which she had been laid in 1973 while she was a student at the National School Dunderrow.

\subsection{Article 3 "Investigation"}

Thanks to a denouncement made in 1995 against L.H's sexual abuse and further investigation of Ms. O'Keeffe was given the opportunity to make a denunciation. The investigation ended in L.H's detention after his admission to some of the allegations raised.

The Court found that there was no violation of Article 3 concerning the "investigation"' for complaints of sexual abuse of Ms. O'Keefe in school. Once L.H had accepted charges brought against him for sexual relations with minors, even with Ms. O'Keefe. ${ }^{12}$

The court decided with 11 votes Pro and 6 Against that was violated the Article 13. It also emphasized that "None of national remedies claimed the Government that existed had not enabled, to ensure for Ms. O'Keefe protection from sexual abuse.

The court also ruled that the Irish state should pay Ms. O'Keeffe about 30,000 EURO, for the Civil Lawsuit raised by her and 85,000 EURO for procedural costs and expenses.

\section{Conclusion}

The above decision it seemed enormously interesting, because it condemns State for failing to take measures necessary to prevent sexual abuse against minors. I think also that this is an institutional responsibility, which should be extended itno many decisions that must be provided by the Albanian courts, improving the decision granting the protection of minors becoming precedent for having in continuity an adequate justice and achievement of objectives and criteria that need to be part of the big European family.

\section{References}

Fenwick, H. \& Phillipson, G. (2003). "Text, Cases and Materials on Public Law and Human Rights".

O'keefe case vs. Ireland, Key Facts. (2004). Irish Law Times Including Irish Law Log, Volume 22, Round Hall Press.

O'keefe case vs. Ireland. (2012). "European Center for Law and Justice", ApplicationNo. 35810/09.

Puto, A. (2002). "European Convention on Human Rights toward the Albanian Constitution", pg. 145.

European Convention of Human Rights.

Internet Sources

http://www.justice.ie/en/JELR/OKeeffe\%20v\%20Ireland.pdf/Files/OKeeffe\%20v\%20Ireland.pdf. http://hudoc.echr.coe.int/app/conversion/pdf/?library=ECHR\&id=001-1465 40\& file na me=001-146540.pdf. http://humanrights.ie/announcements/okeeffe-ireland-violated-article-3-echr/.

https://www.education.ie/en/Learners/Information/Former-Residents-of-Industrial Schools/riruokeefe_v_irl_judgement_july_2014.pdf. https://www.education.ie/en/Learners/Information/Former-Residents-of-Industrial Schools/riruokeefe_v_ irl_ judgement_july_2014.pdf.

${ }^{12}$ https://www.education.ie/en/Learners/Information/Former-Residents-of-Industrial Schools/riruokeefe_v _irl_judgement_july_2014.pdf. 